\title{
SEM STUDIES ON SPORANGIA AND POLLEN MORPHOLOGY OF GINKGO BILOBA CULTIVARS
}

\author{
MaŁgorzata Klimko, Joanna Bykowska, StanisŁawa Korszun
}

\begin{abstract}
M. Klimko, Department of Botany, Poznań University of Life Sciences, Wojska Polskiego 71 C, 60-625 Poznań, Poland, e-mail: klim@up.poznan.pl

J. Bykowska, S. Korszun, Department of Dendrology, Pomology and Nursery, Poznań University of Life Sciences, Dąbrowskiego 159, 60-594 Poznań, Poland, e-mail: jozal@up.poznan.pl
\end{abstract}

(Received: July 20, 2016. Accepted: August 25, 2016)

\begin{abstract}
AвSTRAct. The present study was conducted to illustrate the micromorphology of mature sporangia and pollen grains of four Ginkgo biloba cultivars: 'Horizontalis', 'Lasiocarpa', 'Pragensis' and 'Tubifolia' and is a continuation of earlier investigations on this subject. The sporophylls bear typically two pendulous sporangia, whereas three were found in one cultivar. The sporangia varied in shape from oval, elliptical elongate to boat-shaped and dehisced along a longitudinal slit. The sporangial walls are multilayered. The sculpture of the sporangium is rugose covered with wax crystals (tubules) and the endothecium shows clearly visible fibrous thickening on the wall. The pollen grains are monosulcate, the non-apertural surface is irregularly ridged (striate) or rugulate, with perforations and the germinal aperture (furrow) is covered with verrucae. The current study did not differentiate significantly four cultivars based on sporangia and pollen morphology. The micromorphological traits may be useful for identification and classification of fragments of fossil sporangia and pollen grains.
\end{abstract}

KEY WORDS: Ginkgo biloba, male cone, sporangial wall, pollen grains, LM, SEM

\section{INTRODUCTION}

Ginkgo biloba L., one of the most primitive extant gymnosperms, is the only living species of the ancient lineage of Ginkgophyta (ZHOU \& ZHENG 2003). It medicinal properties have been known and its decorative value has been appreciated since antiquity. Leaves of an unusual shape and venation as well as edible seeds used for medicinal purposes probably contributed to the popularisation of this species in China and Korea (Li 1956). In China G. biloba used to be planted mainly around Buddhist and Taoist temples (Del Tredici 2000). In the $12^{\text {th }}$ century this species was introduced in western Japan (Tsumura et al. 1992) and from there it reached Europe six centuries later. The first G. biloba tree in the Old Continent was planted around 1730 in Holland, in the Utrecht Botanical Garden. Fascination with this unusual species resulted in its rapid spread throughout Europe and its introduction in North America in 1784 (DEL TredicI 1991).

Over the last decades more than 200 G. biloba cultivars have been selected and bred (SANTAMOuR et al.
1983, Li et al. 2013, our own information - S.K.), differing in habit or shape and size of their leaf blades. Curently, the cultivar systems of G. biloba are confused.

At present G. biloba is commonly planted as an ornamental tree in parks and along streets, while it is grown as a medicinal plant mainly in China, Korea, France, Germany and the United States (SINGH et al. 2008). In the opinion of SinClair et al. (1987), HondA (1997) and SINGH et al. (2008) resistance of G. biloba to pests and pathogens as well as air pollution, including ozone and sulphur dioxide, makes it a perfect species for urban areas. The trees are dioecious. The male trees are more desirable for planting, because female plants produce foul-smelling seeds (SINGH et al. 2008). The pollen-bearing organs are catkin-like and originate singly in the leaf axis of short shoots. Each sporangiophore consists of a stalk and a sterile extension and each bears two (rarely more) pendant pollen sacs, which dehisce with a longitudinal slit. The sporangial walls are multilayerd (PAGE 1990). The pollen grains of $G$. biloba possess one simple aperture that extends from one extremity of the pol- 
len grain to the other. The terms used to describe the aperture of these pollen grains vary from monocolpate to one sulcate (ERDTMAN 1952, YAMAZAKI \& TAKEOKA 1962, NAKAMURA 1980, Liu et al. 2006). The dry and acetolised pollen grains are boat-shaped with a single longitudinal furrow. However, fully swollen grains are also observed, being spherical with a rounded or oval germinal aperture, bordered by a rim from the proximal hemisphere and differing in sculpture (SAHASHI \& Ueno 1986).

The aims of our study were to examine and describe sporangia and pollen morphology of four, previously not studied Ginkgo biloba cultivars and to determinate their characters for systematic importance.

\section{MATERIAL AND METHODS}

Sporangia of G. biloba were collected by the authors in May, 2015 from four cultivated plants: 'Horizontalis', 'Lasiocarpa', 'Pragensis' and 'Tubifolia'. They were selected from around 60 varieties in the collection of the Department of Dendrology, Pomology and Nursery, Poznań University of Life Sciences, Poland. Each specimen was represented by 15 pollen cones. The pollen grains were studied by light microscopy (LM) and SEM to obtain comprehensive information concerning the general morphology and exine sculpture. The SEM examinations were made on pollen grains which were air-dried, while for LM examinations pollen was treated with $10 \% \mathrm{KOH}$ (FrEDERIKSEN 1978, Korszun \& KLIMKo 2014) and without chemical treatment. The length of the polar axis $(\mathrm{P})$ and equatorial axis (E) were measured in 100 pollen grains per specimen and the $\mathrm{P} / \mathrm{E}$ ratio was calculated. The arithmetical mean and standard deviation were calculated for each mentioned trait (Table 1). The biometric data were analysed statistically. For each pollen grain feature, one-way analysis of variance (ANOVA) was used to examine differences in means between the cultivars studied. If significant differences were observed, multiple comparisons were carried out based on Tukey's test for equal sample sizes. Statistical analyses were performed using Statistica 12.5 (StatSoft, Poland). Micrographs were taken with a SEM type EVO 40 microscope (Carl Zeiss, Jena, Germany) at an accelerating voltage of $15 \mathrm{kV}$, at the Confocal and Electron Microscopy Laboratory, the Faculty of Biology, the Adam Mickiewicz University, Pozna, Poland. Prior to the observations the prepared material was sputtered with gold (for $15 \mathrm{~s}$ ) using an SCB 050 ion sputter (Balzers AG, Liechtenstein). The study was documented with photographs taken during the observations, primarily at a magnification $\times 150$ and surface from $\times 2000$ to $\times 20000$ for sporangia, for pollen grains $\times 8000$ and from $\times 20000$ to $\times 35000$ for exine sculpture. Micromorphological traits of sporangia were observed on the dorsal and exine surfaces in the proximal and distal view. With regard to the sporangial surface, mainly the terminology of BARTHLOtT (1981) was applied. The pollen terminology was adopted from FÆGRI \& IVERSEN (1964), while the shape classification followed that of ERDTMAN (1952) based on the P/E ratio (Table 1).

\section{RESULTS}

\section{DESCRIPTION OF POLLEN CONE}

The sporophylls bear mainly two pendulous sporangia, whereas three were observed in cv. Tubifolia (Fig. 1e). The mean length ranged from 1.32 to 1.50 $\mathrm{mm}$, width from 0.75 to $0.86 \mathrm{~mm}$, while the length/ width ratio from 1.61 to 2.03 (Table 1). The coefficient of variation for length ranged from $9.1 \%$ ('Horizontalis') to $21.6 \%$ ('Tubifolia'), for width from $3.3 \%$ ('Tubifolia') to $23.2 \%$ ('Horizontalis') and for the length/width ratio it ranged from $15.5 \%$ ('Lasiocarpa') to $21.1 \%$ ('Horizontalis') (Table 1).

The sporangia in the examined cultivars were oval (Fig. 1a, e) or elongate-elliptical (Fig. 1c) in all taxa and dehisced along a longitudinal slit (Fig. 1c). The surface was rugose and cell shape was not visible in SEM (Fig. 1b, d, f). The dorsal and ventral surfaces were convex. The cuticular layer covering the sporangial wall was broken into irregularly shaped (Fig. 1b, $\mathrm{d}, \mathrm{f}$ ) and covered densely with wax crystals (tubules) (Fig. 1g, h). The sporangia were eusporangiate and consisted of the epidermis, endothecium and the tapetum. The endothecium cells in LM were polygonal or elongated at the dehiscence of the sporangium with a clearly visible fibrous thickening on the wall (Fig. 2a-d).

\section{DESCRIPTION OF POLLEN GRAINS}

General morphology of pollen grains was similar, as all were distally monosulcate. The mean length of pollen grains (without chemical treatment) was from $35.82 \mu \mathrm{m}$ ('Horizontalis') to $41.66 \mu \mathrm{m}$ ('Tubifolia'), while width ranged from $18.92 \mu \mathrm{m}$ ('Lasiocarpa') to $24.65 \mu \mathrm{m}$ ('Tubifolia') (Table 1). In cv. Horizontalis $5.88 \%$ pollen grains were subprolate and $94.4 \%$ prolate. In 'Lasiocarpa' $31.82 \%$ pollen grains were prolate and $68.16 \%$ perprolate. In 'Pragensis' $77.27 \%$ pollen grains were prolate and $22.72 \%$ perprolate, while in 'Tubifolia' $89.47 \%$ pollen grains were prolate and $10.52 \%$ perprolate. Prolate pollen was predominant in three cultivars, i.e. 'Horizontalis', 'Pragensis' and 'Tubifolia'. Perprolate pollen was found in 'Lasiocarpa' with the $\mathrm{P} / \mathrm{E}$ ratio of 2.13 . Values of $\mathrm{P}, \mathrm{E}$ and $\mathrm{P} / \mathrm{E}$ showed low variability: for $\mathrm{P}$ it ranged from $7.8 \%$ ('Lasiocarpa') to $13.0 \%$ ('Tubifolia'), for E it was from $9.6 \%$ ('Tubifolia') to 18.9 ('Horizontalis'), whereas for the P/E ratio it was from $13.1 \%$ ('Lasiocarpa') to $14.8 \%$ ('Tubifolia'). Pollen grains were medium-sized according to ERDTMAN's classification 


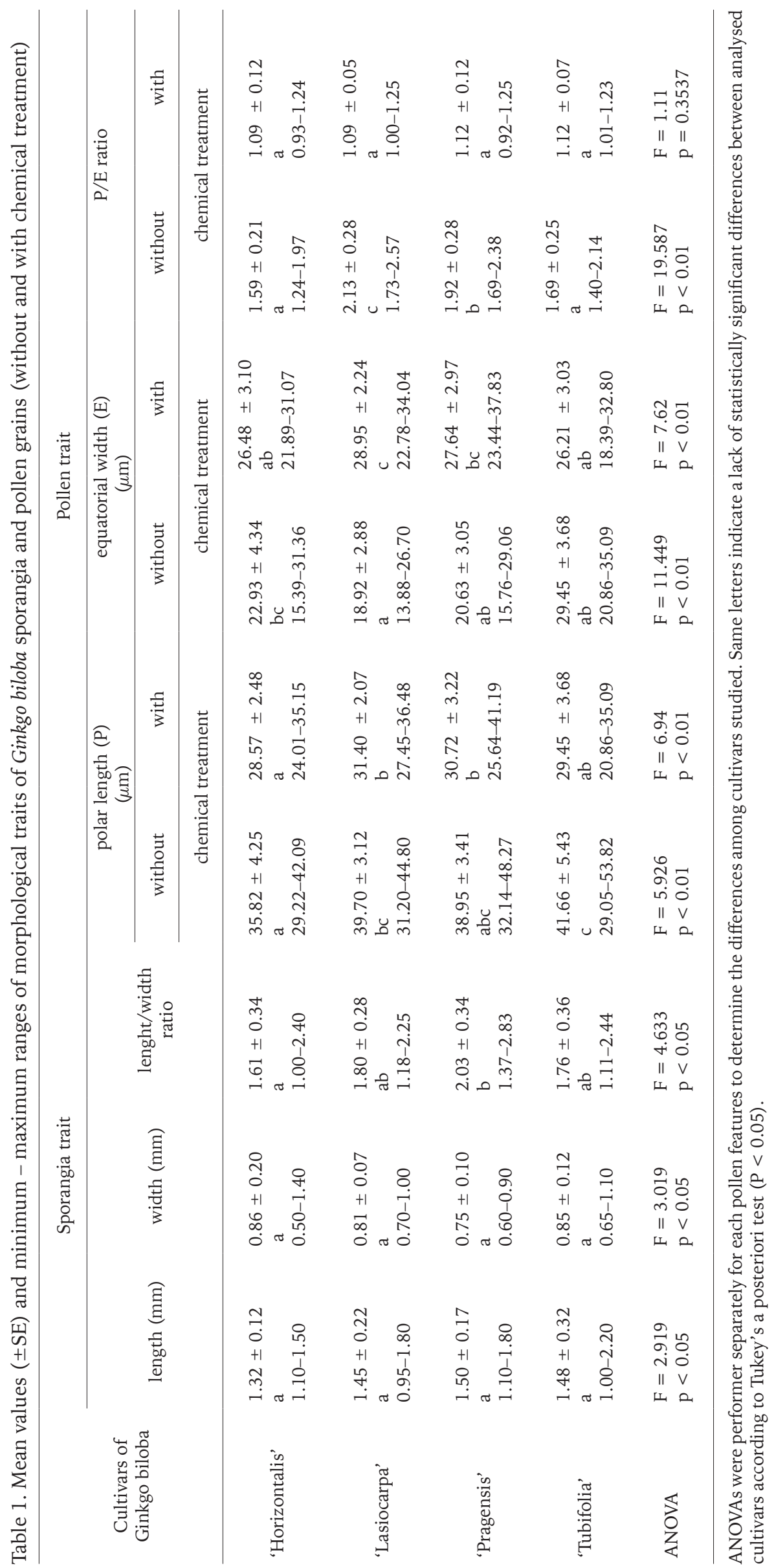



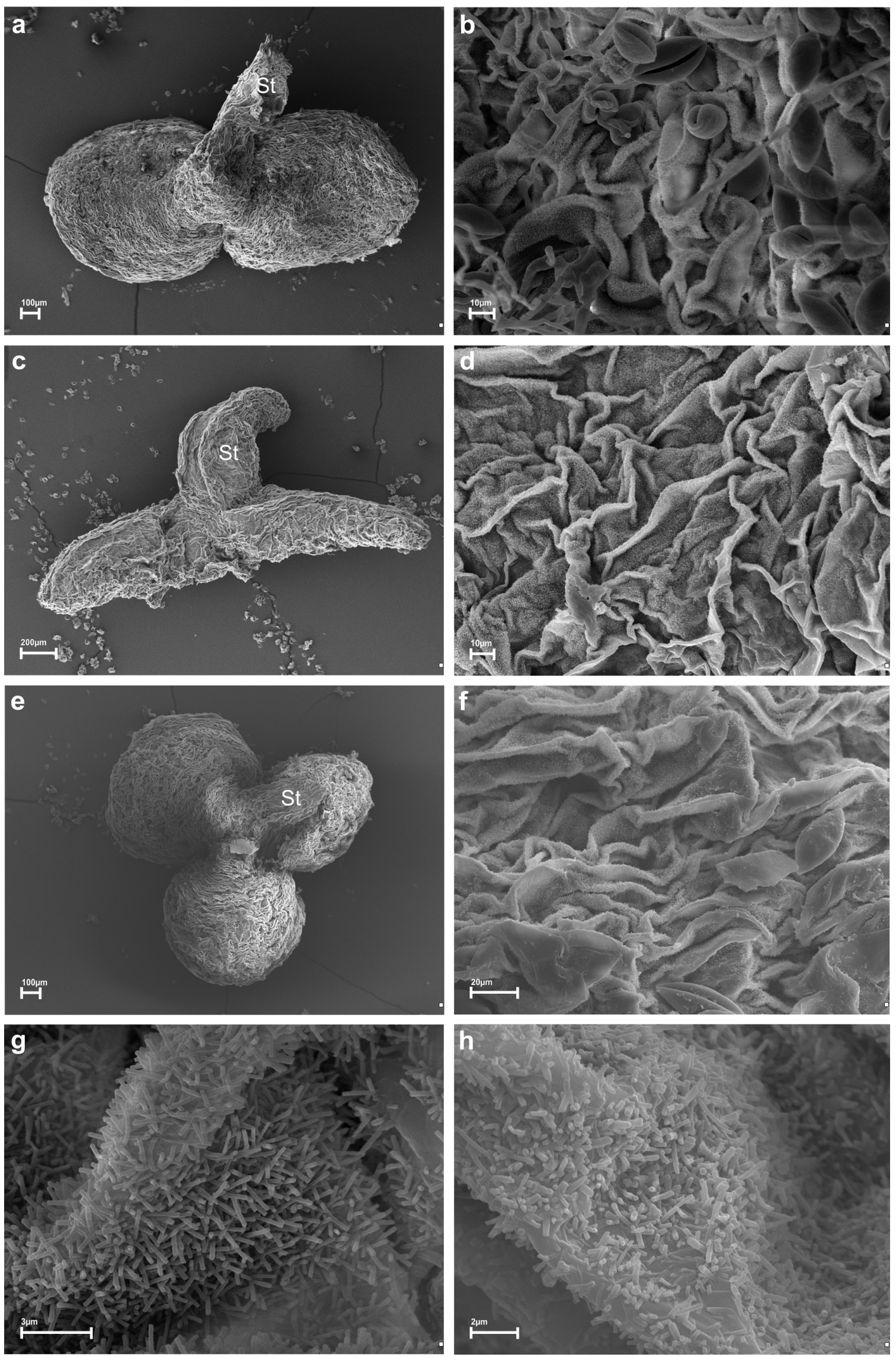

Fig. 1. SEM micrographs of sporangia of Ginkgo biloba: (a, b) 'Horizontalis' and (c, d) 'Pragensis', sporophyll bearing two sporangia, (e, f) 'Tubifolia' sporophyll bearing three sporangia. Crystaloid wax (tubules) on sporangia, (g) 'Horizontalis', (h) 'Tubifolia'; St - stalk 

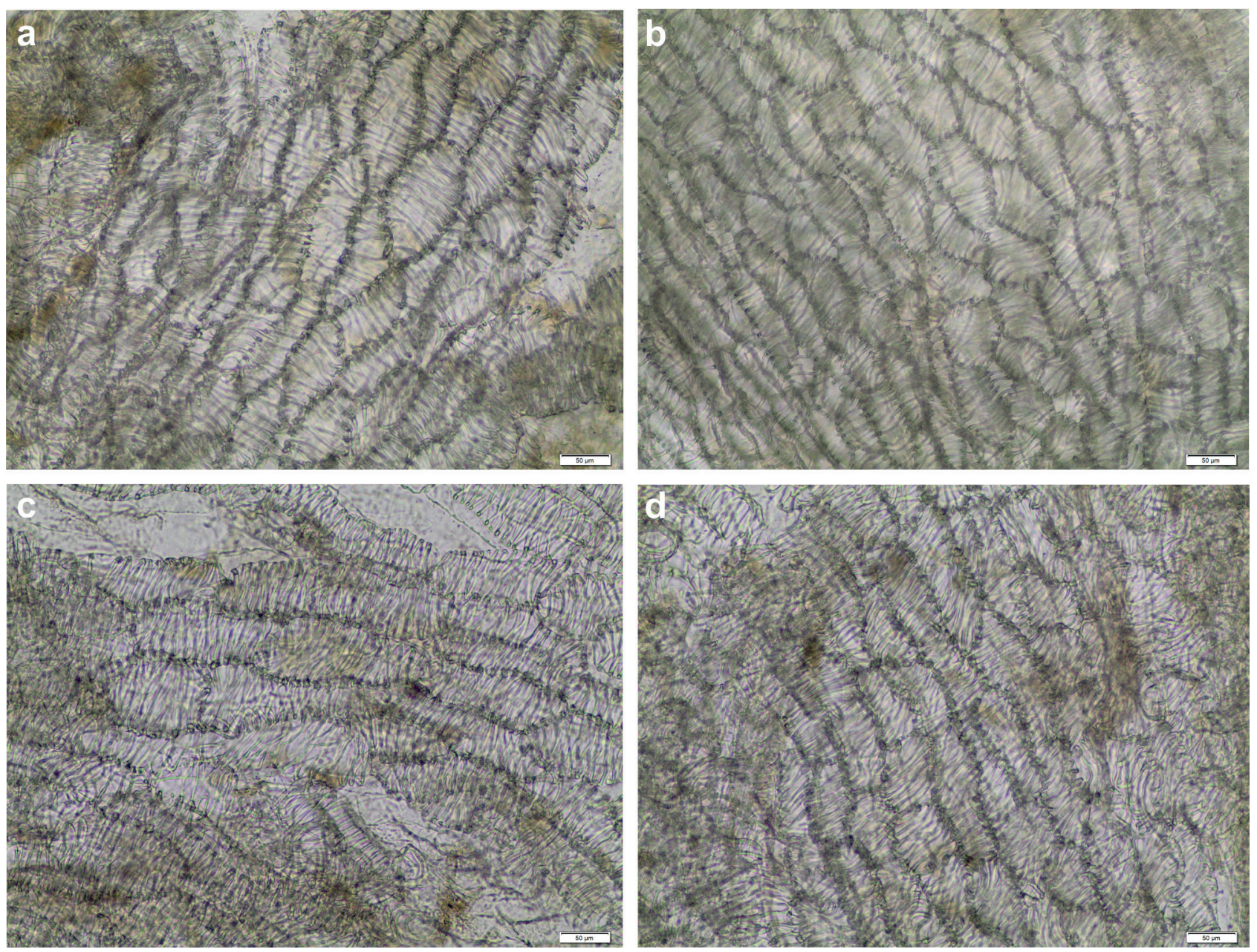

Fig. 2. LM. Fibrous thickening on endothecium walls of Ginkgo biloba: (a) 'Horizontalis', (b) 'Lasiocarpa', (c) 'Pragensis', (d) 'Tubifolia'

(1952). Exine sculpturing was observed in SEM on the proximal (Figs 3a-c, d, g, h; 4a-c, f- h) and distal views of boat-shaped pollen (air-dried). The proximal surface has the same sculpturing as the distal surface (Figs 3f, i, j; 4d, e i, j), but variance in exine sculpturing was observed between the non-apertural and apertural areas (Figs 3f, j; 4e, j). Ornamentation on the proximal face was irregularly ridged (striate) in G. biloba 'Horizontalis' (Fig. 3a-d) and in 'Lasiocarpa' (Fig. 4a, b, c); rugulate and irregularly ridged in 'Pragensis' (Fig. 4h) and rugulate in 'Tubifolia' (Fig. $3 g, h)$. The enlarged proximal surfaces are shown in Figures $3 c, d ; 4 b, c, h$. It had very clearly visible perforations (irregular pores, holes) and small granules. The ornamentation observed on the outer face of the germinal aperture (furrow) of Ginkgo pollen grains under SEM was similar and covered with verrucae (Figs 3f, j; 4e, j).

The mean length of pollen grains (with chemical treatment) was from $28.57 \mu \mathrm{m}$ ('Horizontalis') to $31.40 \mu \mathrm{m}$ ('Lasiocarpa') and width from 26.21 $\mu \mathrm{m}$ ('Tubifolia') to $28.95 \mu \mathrm{m}$ ('Lasiocarpa'). Prolate-spheroidal pollen was predominant in all the cultivars with a P/E ratio from 1.09 to 1.12 (Table
1). However, pollen grains were oblate-spheroidal, prolate-spheroidal and subprolate. In 'Lasiocarpa' $3.84 \%$, 'Pragensis' $10.12 \%$ and 'Horizontalis' $31.6 \%$ pollen grains were oblate-spheroidal. In 'Horizontalis', 'Pragensis' and 'Lasiocarpa' 52.03\%, 70.08\% and $88.5 \%$ pollen grains were prolate-spheroidal. A total of $7.7 \%$ 'Lasiocarpa', $10.5 \%$ 'Horizontalis', $22.6 \%$ 'Pragensis' and $29.2 \%$ 'Tubifolia' pollen grains were subprolate. Values of P, E and P/E showed low variability: for $\mathrm{P}$ it was from $3.5 \%$ ('Horizontalis') to $12.5 \%$ ('Tubifolia'); for E from $7.7 \%$ ('Lasiocarpa') to $11.7 \%$ ('Horizontalis') and P/E from $4.6 \%$ ('Lasiocarpa') to $11.1 \%$ ('Horizontalis'). Exine sculpturing in our study was difficult to describe on LM images (Fig. 5).

\section{DISCUSSION}

The application of a greater magnification in SEM showed that the wax covering the sporangial wall was crystals (tubules), not platelets (Korszun \& Kцiмко 2014). The type of wax is a good diagnostic feature for Ginkgo, because it is found on generative and vegetative organs (Riederer 1989, Majumder et 

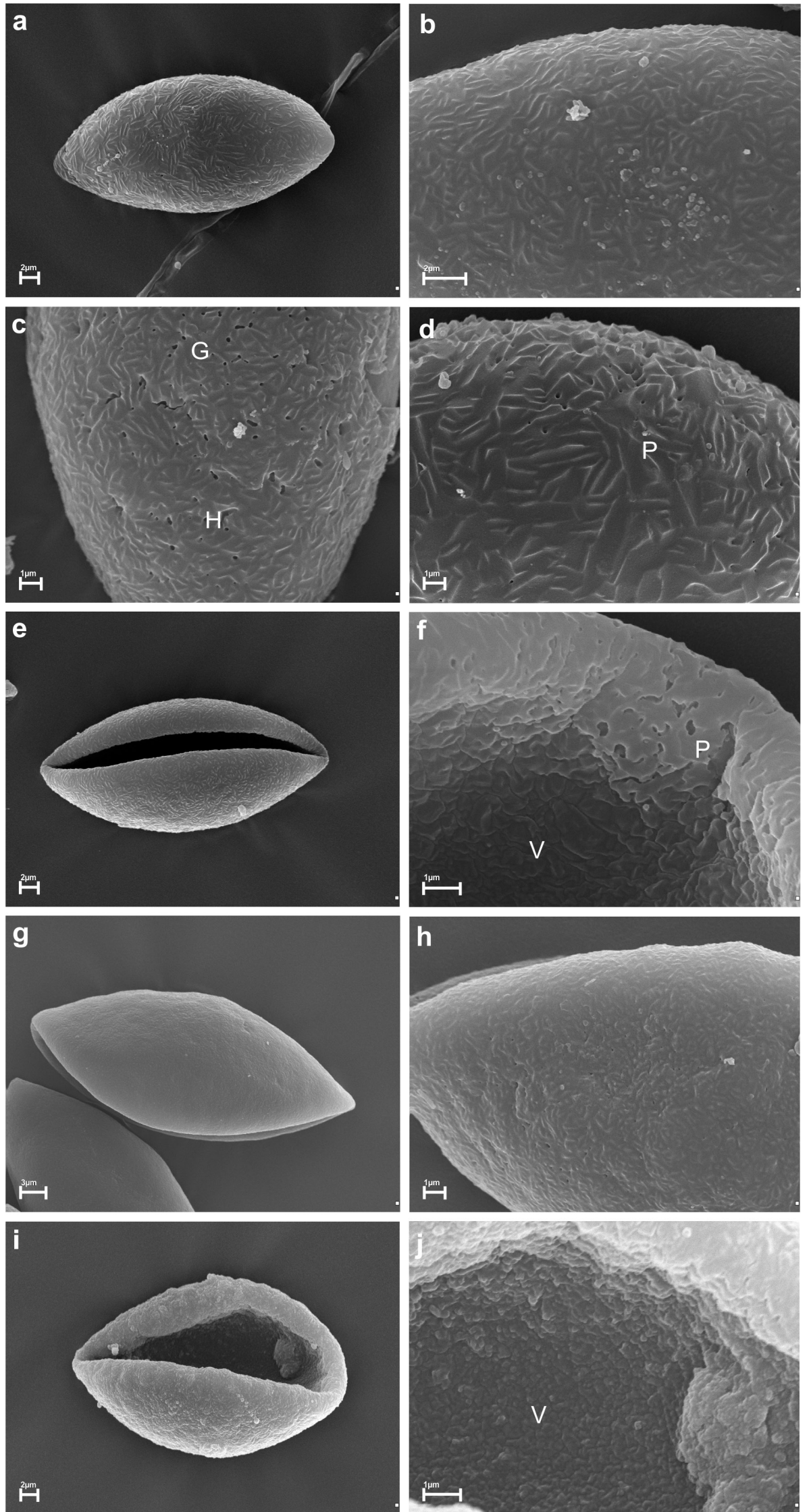

Fig. 3. SEM micrographs of pollen grain of Ginkgo biloba: (a-f) 'Horizontalis', (a) proximal view, (b, c), proximal surface, enlargement of (a), (d) proximal surface, (e) distal view, (f) distal face of germinal aperture surface, (g-j) 'Tubifolia', (g) proximal view, (h) enlargement of (g), (i) distal view, (j) distal face of germinal aperture surface; $G-$ grana, $H-$ holes, $P$ - puncta, $V$ - verrucae 

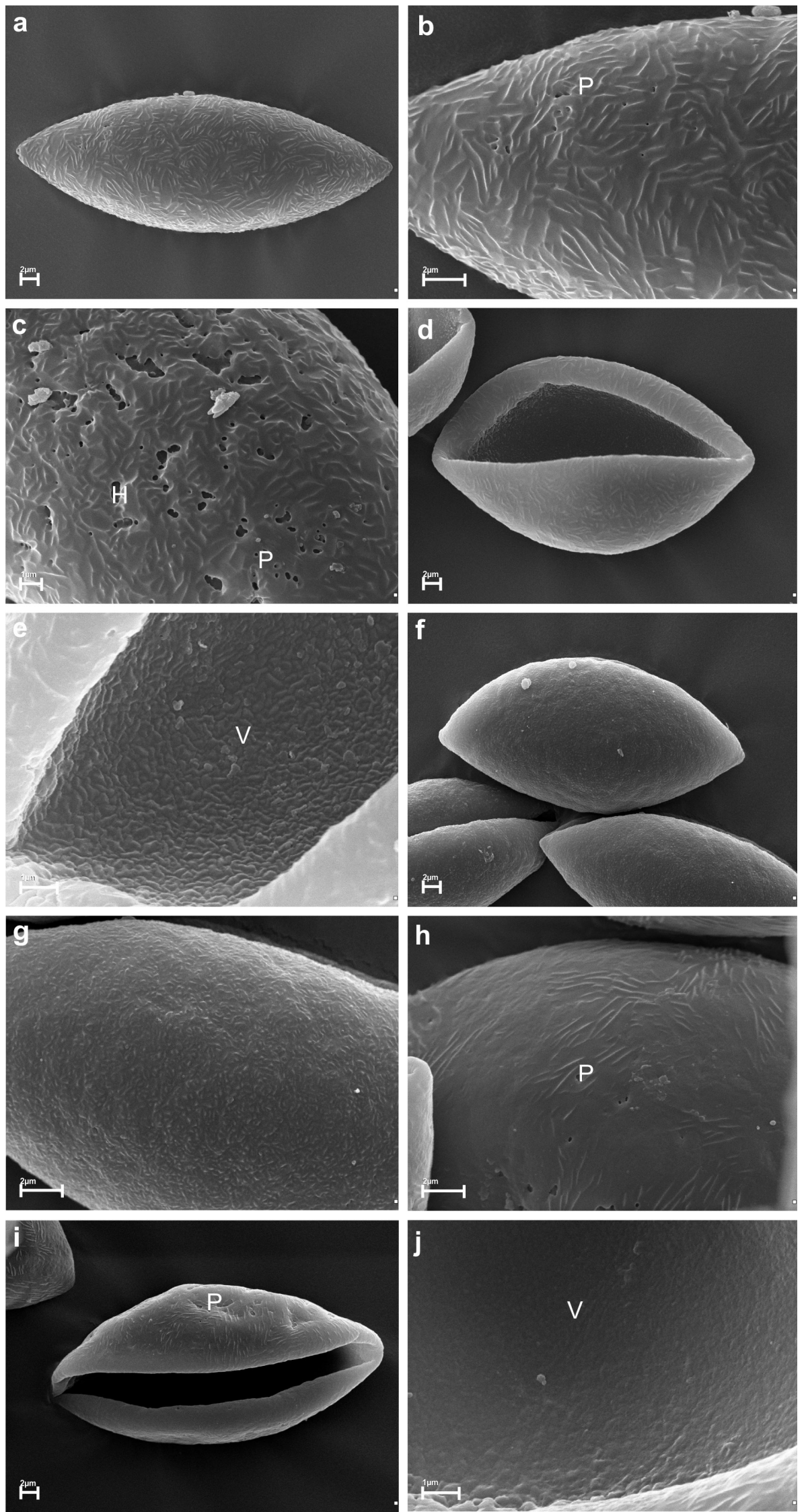

Fig. 4. SEM micrographs of pollen grain of Ginkgo biloba: (a-e) 'Lasiocarpa', (a) proximal view, (b) proximal surface, enlargement of (a), (c) proximal surface, (d) distal view, (e) distal face of germinal aperture surface, (f-j) 'Pragensis', (f) proximal view, $(\mathrm{g}, \mathrm{h})$ proximal surface, (i) distal view, (j) distal face of germinal aperture surface; $H-$ holes, $P$ - puncta, $V$ - verrucae 
al. 2013, Tomaszewski \& ZielińsKi 2014, KLimko et al. 2015, 2016). In other gymnosperms wax layers were studied on vegetative organs e.g. in Cryptomeria japonica D. Don, Taxodium distichum (L.) Rich., Taxus baccata L., T. cuspidate Siebold et Zucc., and Sequoia sempervirens (D. Don) End., and wax tubules and in G. biloba platelets (NeINHUIs \& BARThLOTT 1997). The sporangia were eusporangiate and consisted of the epidermis, endothecium and the tapetum (Lu et al. 2011). Lu et al. (2011) reported that in early April a fibrous thickening was detected in the outer endothecium wall. Our description is consistent with earlier findings by Liu et al. (2006), Lu et al. (2011) and Korszun \& KLimKo (2014). However, this study showed that $G$. biloba cultivars had smaller sporangia than it had been reported previously (LiU et al. 2006, Lu et al. 2011, Korszun \& KLimko 2014). In cultivars described by Korszun \& KLIMKo (2014) the mean size of sporangia was $1.3-3.25 \times 0.37-1.5 \mathrm{~mm}$, while in our study it was $1.32-1.5 \times 0.75-0.86 \mathrm{~mm}$. In turn, they were very similar in shape, i.e. most typically oval or elongate-elliptical. Greater differences were observed in pollen grain size. Pollen grain preparation for analyses was significant. In the cultivars examined by Korszun \& KLIMKO (2014) chemically treated pollen grains were on average 36.72-39.33 $\mu \mathrm{m}$ in length (P) and 15.03-16.02 $\mu \mathrm{m}$ in width (E). In turn, in our study pollen grains not subjected to chemical treatment were larger and had 35.82-41.66 $\mu \mathrm{m}$ in length (P) and 18.92-24.65 $\mu \mathrm{m}$ in width (E). Those chemically treated were much smaller, with 28.57-31.40 $\mu \mathrm{m}$ in length (P) and 26.21-28.95 $\mu \mathrm{m}$ in width (E). Moreover, described pollen grains differed in shape. In the cultivars analysed by Korszun \& Kıimko (2014) the P/E ratio was 2.3-2.49, while in those used in this study it was 1.59-2.13 (pollen grains not treated chemically) or 1.09-1.12 (pollen grains treated chemically).

The proximal surfaces of pollen grains have very clearly visible perforations (irregular pores, holes) and small granules. In contrast, SAHASHI (1997) reported that perforations were almost invisible on the surface without chemical treatment. The ornamentation on the outer face of the germinal aperture (furrow) of Ginkgo pollen grains under SEM was similar and covered with verrucae. According to SAHASHI \& UENO (1986), the inner face of the exine of the germinal aperture in Ginkgo pollen grains, which can be
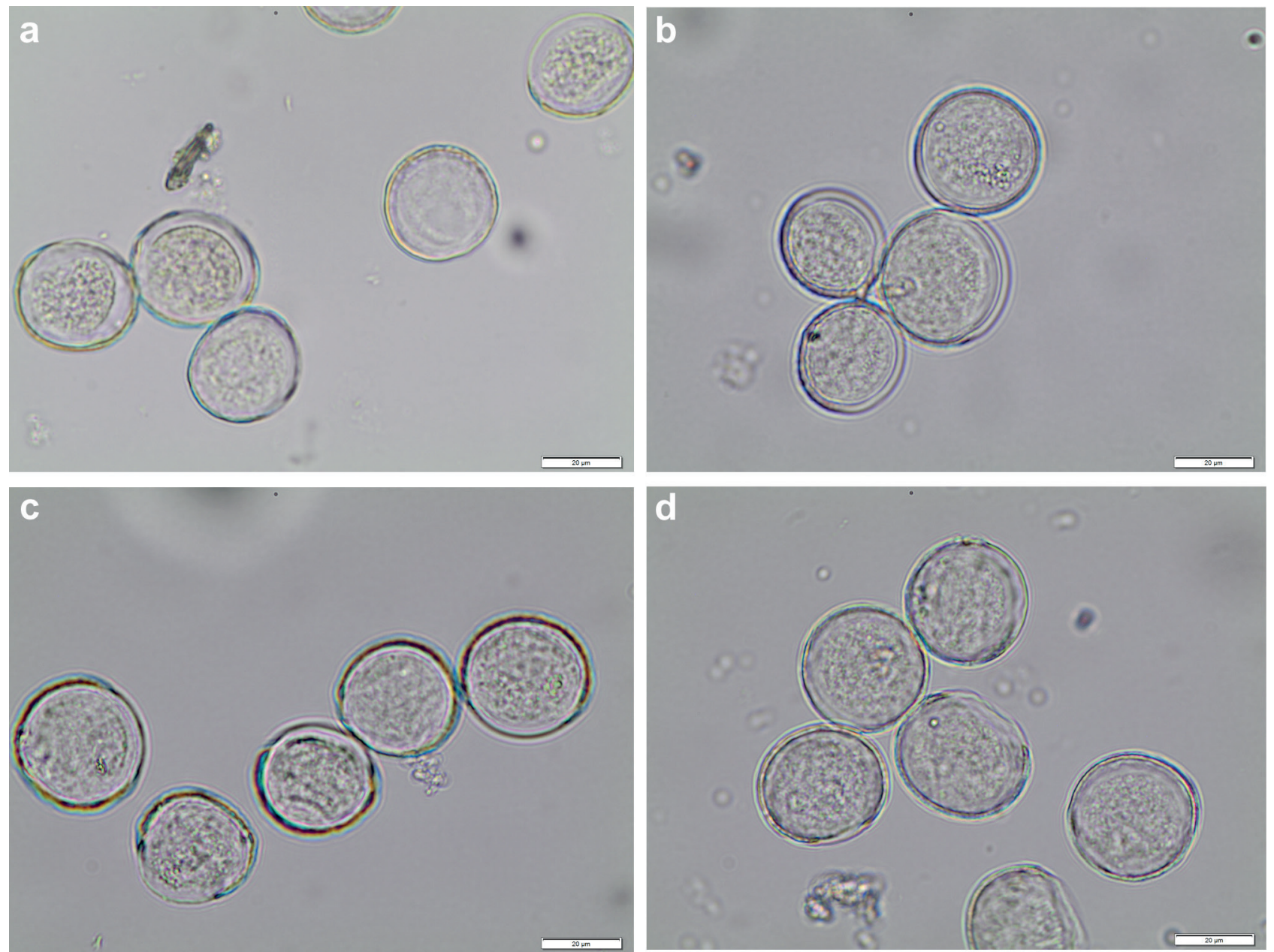

Fig. 5. LM. Groups of pollen grains (with chemical treatment) of Ginkgo biloba: (a) 'Horizontalis', (b) 'Lasiocarpa', (c) 'Pragensis', (d) 'Tubifolia' 
seen in sections, has quite remarkable reticulum-like sculpturing.

Ornamentation seen on the proximal face (without chemical treatment) of pollen grains in SEM was described by SAHASHI (1997) as randomly arranged linear ridges with some granules, as covered by arranged ridges, with minute verrucoid details between the ridges by YAMAZAKI \& TAKEOKA (1962), spinulous by UENO (1960) or reticulate with short and slightly elevated crests by RoHr (1977), and covered with rugules by Audran \& Masure (1978), Zavialova et al. (2011). The pollen grains do not have one strict pattern even within the same tree (KoRszun \& KLIMKO 2014 , this study). Ornamentation seen on chemically treated pollen grains in LM was described as minutely roughened by WODEHOUSE (1935), subreticulate or with a spiny wave by YAMAZAKI \& TAKEOKA (1962), as granulate by SHIMAKURA (1973) and as verrucate by NaKamura (1980). SAHAShi (1997), TekLeva et al. (2007) and Zavialova et al. $(2011,2014)$ published photos of pollen grain with a concave aperture, with swollen apertural areas, an apertural area with a rim and a rugulate sculpture on the proximal surface in SEM images (materials were dehydrated and treated by critical point drying). After acetolysis the ornamentation was foveolate, perforated with tiny holes (FREDERIKSEN 1978) or with clear linear ridges without granules (SAHASHI 1997). As it was shown by analyses conducted to date, the size, shape and ornamentation of pollen grain exine are influenced by the method of specimen preparation.

Our results showed that Ginkgo biloba cultivars cannot be separated based on sporangia and pollen grain micromorphology. Statistical analysis showed no significant differences between cultivars in the means of sporangia and pollen grains. Ornamentation of air-dried pollen grains does not have one strict pattern even within the same tree, e.g. G. biloba 'Pragensis'. This conclusion correlates to the findings reported previously. The micromorphological traits may be useful for identification and classification of fragments of fossil sporangia and pollen grains.

\section{ACKNOWLEDGEMENTS}

We are grateful to Wojciech Klimko for his assistance with computer data recording. The authors would like to thank two anonymous reviewers for their suggestions and comments made on an earlier version of the manuscript. The study was partly supported by the Department of Botany and the Department of Dendrology, Pomology and Nursery, the Poznań University of Life Sciences.

\section{REFERENCES}

Audran J.C., Masure E. (1978): La sculpture et l'infrastructure du sporoderme de Ginkgo biloba com- parées à celles des enveloppes polliniques des Cycadales. Review of Paleobotany and Palynology 26: 363-387.

BARThlotT W. (1981): Epidermal and seed surface characters of plants: systematic applicability and some evolutionary aspects. Nordic Journal of Botany $1: 345-354$.

Del Tredici P. (1991): Ginkgos and people: a thousand years of interaction. Arnoldia 51: 2-15.

Del Tredici P. (2000): The evolution, ecology, and cultivation of Ginkgo biloba. Harwood Academic Publishers: 7-23.

ERdTMAN G. (1952): Pollen morphology and plant taxonomy. Angiosperms: An introduction to palynology. Almqvist \& Wiksell, Stockholm.

FÆGRI K., IVERSEN J. (1964): Textbook of pollen analysis. J. Wiley \& Sons, Chichester.

Frederiksen N.O. (1978): Preservation of Cycad and Ginkgo pollen. Review of Paleobotany and Palynology 25: $163-179$.

HondA H. (1997): Ginkgos and insects. In: T. Hori, R.W. Ridge, W. Tulecke, P. Del Tredici, J. Tremouillaux-Guiller, H. Tobe (eds). Ginkgo biloba. A global treasure. Springer Verlag, Tokyo: 243-250.

Kuimko M., Korszun S., Bykowska J. (2015): Comparative morphology and anatomy of the leaves of Ginkgo biloba L. cultivars. Acta Scientiarum Polonorum Hortorum Cultus 14(4): 169-189.

KLimko M., Korszun S., KolasińsKi M. (2016): Seed coat microsculpturing in Ginkgo biloba L. cultivars. Steciana 20(3): 97-101.

Korszun S., KLIMKo M. (2014): Microsporangia and pollen morphology of Ginkgo biloba cultivars. Dendrobiology 71: 83-92.

Li G.P., Zhang C.Q., CAO F.L. (2013): An efficient approach to identify Ginkgo biloba cultivars by using random amplified polymorphic DNA markers with a manual cultivar identification diagram strategy. Genetics and Molecular Research 12(1): 175-182.

Li H.L. (1956): A horticultural and botanical history of Ginkgo. Morris Arboretum Bulletin 7: 3-12.

Liu X.-Q., Li Ch.-S., Wang Y.-F. (2006): The pollen cones of Ginkgo from the Early Cretaceous of China, and their bearing on the evolutionary significance. Botanical Journal of the Linnean Society 152: 133-144.

Lu Y., Wang L., Wang Y., Zhang M., Jin B., Chen P. (2011): Male cone morphogenesis, pollen development and pollen dispersal mechanism in Ginkgo biloba L. Canadian Journal of Plant Science 91: 971-981.

Majumder S., D'rozario A., Bara S. (2013): Occurrence of wax rodlets in seed coat of Ginkgo biloba L. Current Science 104(1): 29-31.

NaKamura J. (1980): Diagnostic characters of pollen grains of Japan. Osaka Museum of Natural History, Osaka. 
Neinhuis C., Barthlott W. (1997): Characterization and distribution of water-repellent self-cleaning plant surfaces. Annals of Botany 79: 667-677.

PAGE C.N. (1990): Ginkgoaceae. In: K.U. Kramer et al. (eds). Pteridophytes and Gymnosperms. Springer Verlag, Berlin-Heidelberg.

RIEDERER M. (1989): The cuticles of conifers: structure, composition and transport properties. In: E.D. Schulze, O.L. Lange, R. Oren (eds). Ecological Studies 77: 157-192.

Rohr R. (1977): Etude comparée de la formation de l'exine au cours de la microsporogénèse chez une Gymnosperme (Taxus baccata) et une préphanérogame (Ginkgo biloba). Cytologia (Tokyo) 42: 157-167.

SAHASHI N. (1997): Pollen morphology of Ginkgo biloba In: T. Hori et al. (eds). Ginkgo biloba. A global treasure. Springer Verlag, Tokyo: 17-28.

Sahashi N., Ueno J. (1986): Pollen morphology of Ginkgo biloba and Cycas revoluta. Canadian Journal of Botany 64: 3075-3078.

Santamour F.S., He S., McArdle A.J. (1983): Checklist of cultivated Ginkgo. Journal of Arboriculture 9(3): 88-92.

SHIMAKURA M. (1973): Palynomorphs of Japanense plants (in Japanense). Osaka Museum of Natural History, Osaka.

SincLair W.A., Lyon H.H., Johnson W.T. (1987): Diseases of trees and shrubs. Cornstock Publishing Associates, Ithaca.

Singh B., Kaur P., Singh R.D., Ahuja P.S. (2008): Biology and chemistry of Ginkgo biloba. Fitoterapia 79(6): 401-418.

Tekleva M.V., Polevova S.V., Zavialova N.E. (2007): On some peculiarities of sporoderm structure in members of the Cycadales and Ginkgoales. Paleontological Journal 41(11): 1162-1178.

TomasZewsKi D., ZieliŃsKi J. (2014): Sequences of epicuticular wax structures along stem in four selected tree species. Biodiversity Research Conservation 35: 9-14.

Tsumura Y., Мотоіке H., Онва K. (1992): Allozyme variation of old Ginkgo biloba memorial trees in western Japan. Canadian Journal of Forest Research 22: 939-944.

UENO J. (1960): On the fine structure of the cell walls of some gymnosperm pollen. Biological Journal of Nara Women's University 10: 19-25.

Wodehouse R.P. (1935): Pollen grains. McGraw-Hill, New York.

YAMAZAKi T., TAKEOKA M. (1962): Electron-microscope investigations of the fine details of the pollen grain surface in Japanese gymnosperms. Grana Palynological 3(2): 3-12.

Zavialova N., Gordenko N., Nosova N., Polevova S. (2014): The fine morphology of pollen grains from the pollen chamber of a supposed ginkgoalean seed from the Middle Jurassic of Uzbekistan (Angren locality). Plant Systematic and Evolution 300(9): 1995-2008.

Zavialova N., Markevich V., Bugdaeva E., Polevova S. (2011): The ultrastructure of fossil dispersed monosulcate pollen from the Early Cretaceous of Transbaikalia, Russia. Grana 50(3): 182-201.

Zhou Z., Zheng S. (2003): The missing link in Ginkgo evolution. Nature 423(6942): 821-822.

For citation: KLIMKo M., ByKowsKa J., Konszun S. (2016): SEM studies on sporangia and pollen morphology of Ginkgo biloba cultivars. Steciana 20(3): 173-182. doi: 10.12657/steciana.020.018 